\title{
Nicolas Lamare
}

\section{Fountains and the Ancient City}

\author{
Social Interactions, Practical Uses, and Pleasant Sights
}

\begin{abstract}
Fountains were remarkable buildings in ancient cities. First, their functional aspect as water suppliers made them essential to daily life. Then, under the Roman Empire, they gradually acquired a role as ornamentation of the space and as a manifestation of the political discourse that modified their architecture and appearance. Because of these dual characteristics, both functional and decorative, fountains, especially monumental fountains, are very appropriate buildings for conducting an analysis of urban space and its perception. Where were the fountains located in the city? How did they fit into the architectural framework? Who frequented them on a daily basis? How did they evolve over time? This article argues that fountains were buildings in their own right, whose practical and decorative functions must be considered in an equivalent way. Focusing on North Africa provinces, it looks at the perception of fountains in the city, as monumental buildings and constructions decorated with water, which is their raison d'être.
\end{abstract}

The image of the Roman city has long been associated with water, mainly because of the arcades of the aqueducts that still dominate the landscape around the ancient towns. The presence of water in cities, both in domestic and public spaces, its abundance and (over)consumption have long been considered essential characteristics of imperial urban space. Among the water-related monuments, fountains are the most representative, because they distributed water and, in the case of the most monumental of them, staged it. A study of these particular buildings addresses several interconnected issues. The architecture and decoration of the fountains allow us to study the staging of power, but also of the profusion of water. In fact, the visual and acoustic dimension of the continuous flow of water in the city is in response to the desire to show the domination of man over the natural elements and the hazards of resource availability and climate change. Moreover, written testimonies make it possible to capture the mental concepts relating to water in the city, which was essential as an element of everyday life and as a characteristic element of urban aesthetics.

Focusing on North Africa provinces with comparisons, this article falls into two parts, the first one dedicated to the Roman imperial period, followed by an investigation devoted to the late antique city, a period for which the problems are different, even though fountains still played an essential role. For each period, three aspects are discussed. First, the location, along with the visibility and accessibility of the fountains will be analysed according to the available sources. In a second part, fountains will be discussed as a meeting point, a place of gathering or recreation, in their social dimension. In a third part, the discussion will focus on the visualisation of fountains, based on architectural data, and on the meaning intended to be given to the monuments, thanks to epigraphic texts. ${ }^{1}$

1 The ideas presented in this article are based on a $\mathrm{PhD}$ dissertation on monumental fountains in Roman North Africa. Cf. Lamare 2019. I would like to thank Annette Haug and Nicola Chiarenza for their invitation to the Urban Water Colloquium, the reviewers for their remarks on my paper, as well as Nichole Sheldrick for improving the first draft of the English text. All mistakes remain my own. All dates are AD.

Ә Open Access. $\odot 2020$ Nicolas Lamare, published by De Gruyter. (c) BY-NC-ND This work is licensed under the Creative Commons Attribution-NonCommercial-NoDerivatives 4.0 License.

https://doi.org/10.1515/9783110677065-003 


\section{Fountains in the imperial city}

\section{Fountains in the heart of the city: displaying water and power}

In general, fountains were located on prominent sites, which must be understood in relation to their iconographic programme, the inscriptions they displayed, and the political context in which they were built. In Caesarea, a fountain must have existed near the south gate of the city and outside the walls. Its construction would have been part of a programme similar to that mentioned in an inscription, dated 201, which evokes the repairing of the road built to enhance the entrance to the city. ${ }^{2}$ This inscription is reminiscent of the mention in the Augustan History of the construction of the septizodium by Septimius Severus, at the southern corner of the Palatine, to make a good impression on the Africans arriving in Rome. ${ }^{3}$ Likewise in the East, at Apameus, the nymphaeum located between the northern gate and the pilaster, constituting the starting point of the great colonnade, was the first intramural building that a visitor would see, thus giving concrete visibility to the emperor's beneficent action that an inscription discovered nearby might highlight. ${ }^{4}$

Fountains adorned, impressed, and were the ideal support for an honorary inscription, whether it was located on the outskirts or in the city itself. ${ }^{5}$ We know of a limited number of African fountains for which the associated honorary inscription is available. The Lacus of Terentius is the most representative example: ${ }^{6}$ located at the crossroads of several lanes, preceded by a stepped platform and composed of a high podium, the honorary inscription ${ }^{7}$ recalled its construction and that of the aqueduct supplying the city, while a base, ${ }^{8}$ which can be assumed to have been surmounted by a statue, commemorated the cura aquarum which was performed by a notable from the city (Fig. 1). The nymphaeum-septizonium of Lambaesis, ${ }^{9}$ according to Michel Janon's reconstruction, highlighted on the entablature the two inscriptions commemorating the construction and restoration of the fountain ${ }^{10}$ along one of the city's major roads (Fig. 2). The fountain, as at Dougga, was located at the point of arrival of the aqueduct in the city and was the place where various inscriptions, recalling the developments carried out at the water source or on the aqueduct, were displayed. The same pattern can be seen in Cuicul, where the inscription on the entablature of the Fountain of the Tetrarchy ${ }^{11}$ mentioned the restoration of a water supply system for the city (Fig. 3). Other fountains, like any monument that was the result of an act of euergetism, presented a conspicuous inscription on their main façade, sometimes according to an arrangement that gave way to a certain originality. The inscription ${ }^{12}$ of the fountain in Calama, if we follow Amable Ravoisié's records, partly followed the curvature of the façade, but also the entablature spur. ${ }^{13}$ In Sbeitla, the fountain to the southwest of the forum was decorated with an inscription, ${ }^{14}$ the text of which was interspersed with the capitals

2 CIL VIII, 20982 = ILS, 5376; Leveau 1984, 27. 56.

3 SHA Sev. 24, 3.

4 AE 2000, 1495; Balty 1972, 20; Vannesse 2011, $191 \mathrm{f}$.

5 See in the East, in Gerasa, two monolithic fountains, placed at the corners of an important crossroads, re-using honorary bases dedicated to Trajan and Hadrian, perhaps to recall that the water supply system had been designed under the reign of the former and put into service under the latter: Seigne 2008, 45-49 fountains nos. 12. 13.

6 Golvin - Garat 2010; Lamare 2019, 378-380 no. 48.

7 CIL VIII, 1480 = 26534 = AE 1966, 511 = AE 1991, 1665 = AE 2000, 1725-1726 = ILTun, 1408 = Dougga, 36.

8 AE 1966, 512 = Dougga 37.

9 Janon 1973; Aupert 1974, 97-101; Letzner 1999, 405-407 no. 249; Lamare 2019, 325-328 no. 16.

10 CIL VIII, 2658 = AE 1973, 645; CIL VIII, 2657 = 18105 = ILS, 5626 = AE, 1973, 645.

11 AE 1920, 15 = ILAlg II 3, 7859.

12 CIL VIII, $5377=5483=5484=17525=$ ILAlg I, 298 .

13 Ravoisié 1846 II, 34 f. pl. 33; Letzner 1999, 398 no. 237.

14 CIL VIII, 234 = 11329 = AE 1958, 158 = ILPSbeitla 84: [DD(ominis) nn(ostris)] / Valenti/niano / et Va/[lente / Augg(ustis) / --- / ---]OTA // [Fontem / --- / ---]lius / Festus / v(ir) c(larissimus) / --- / civibus / [suis d(onum) d(edit)]. 


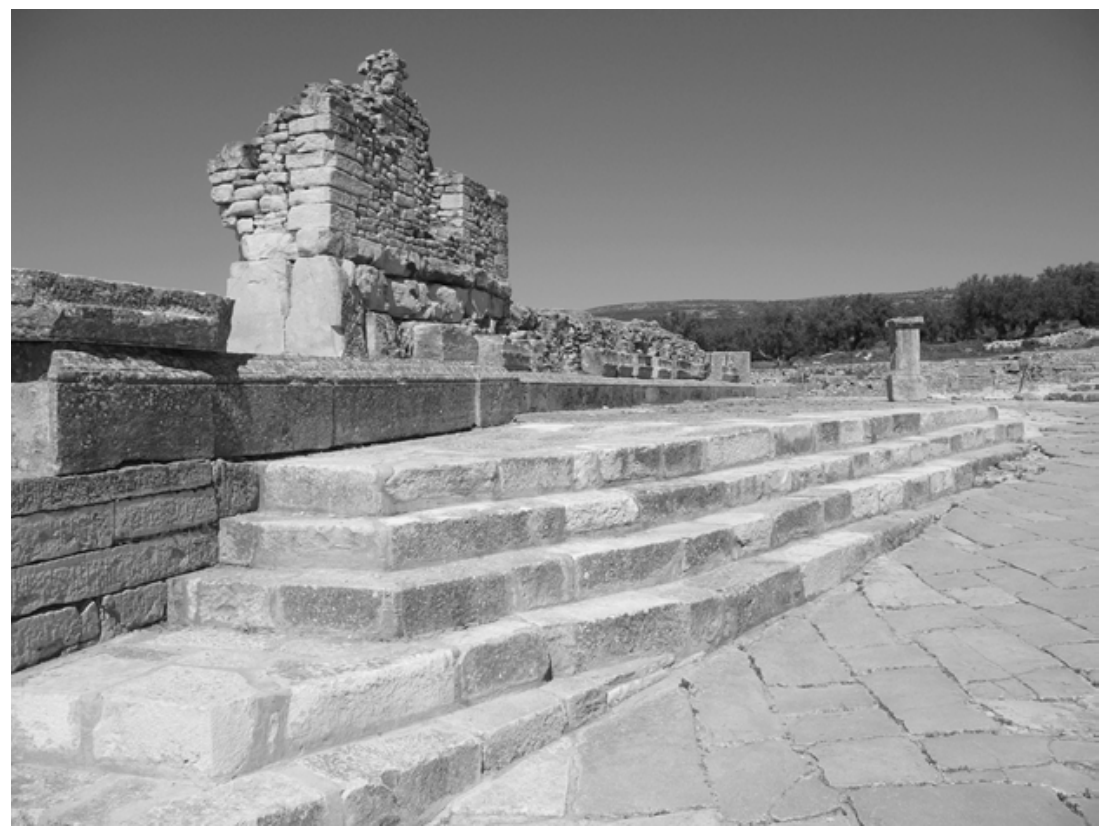

Fig. 1: Dougga, lacus of Terentius, view towards the west. The access staircase to the platform has been restored.

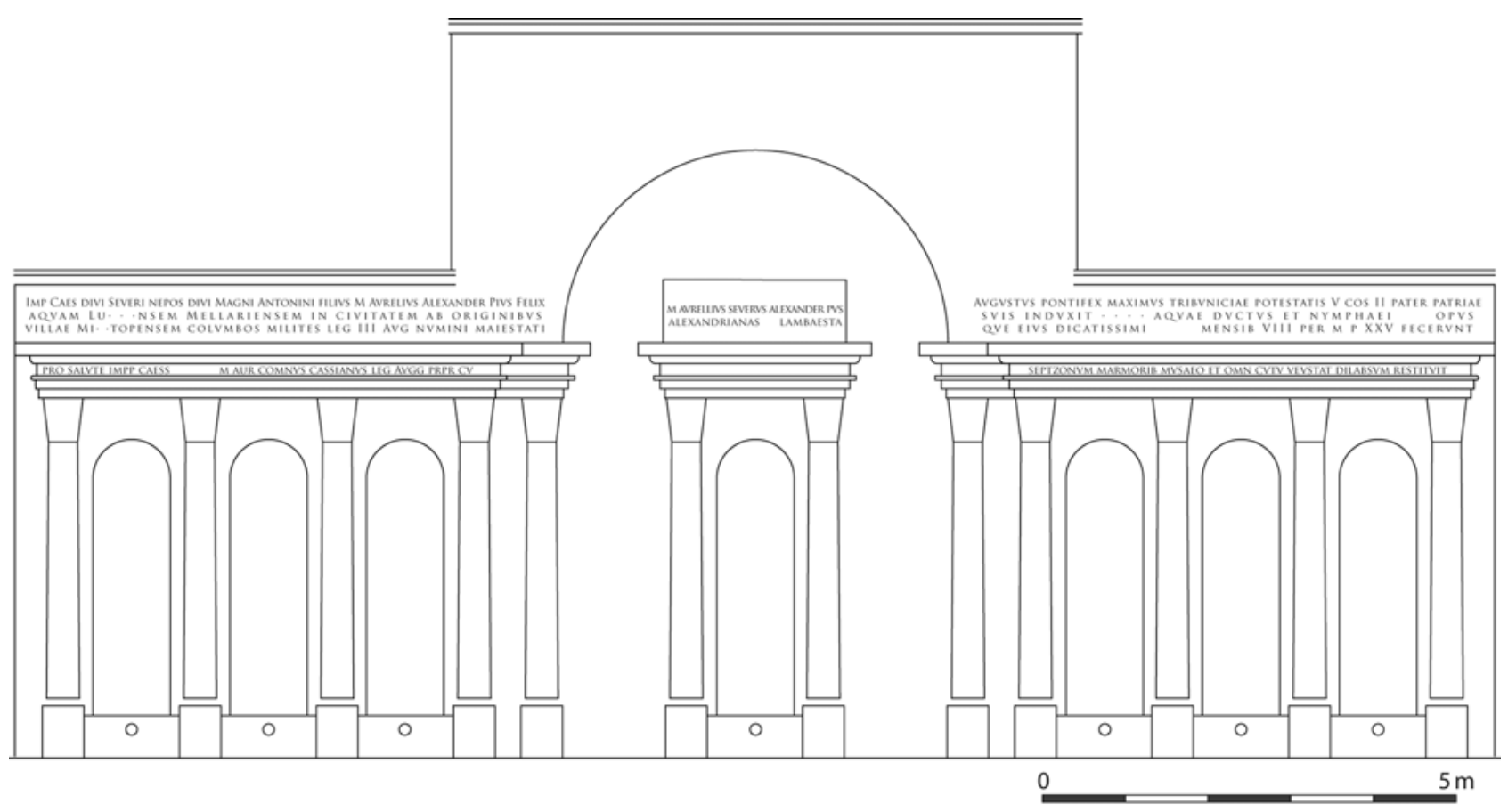

Fig. 2: Lambaesis, restituted elevation of the nymphaeumseptizonium with the inscriptions. 

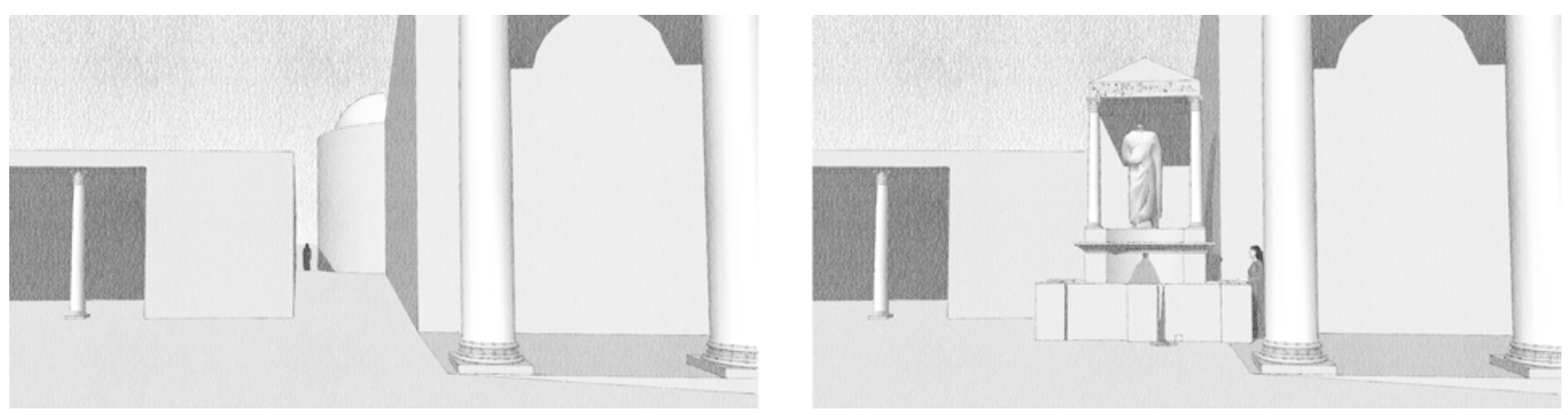

Fig. 3: Cuicul, Fountain of the Tetrarchy, restitution from ground level of the situation before and after the construction of the fountain blocking the street between the House of Bacchus and the Southern Great Baths.

Fig. 4: Sbeitla, Fountain to the southwest of the forum, the inscribed block no. 4.

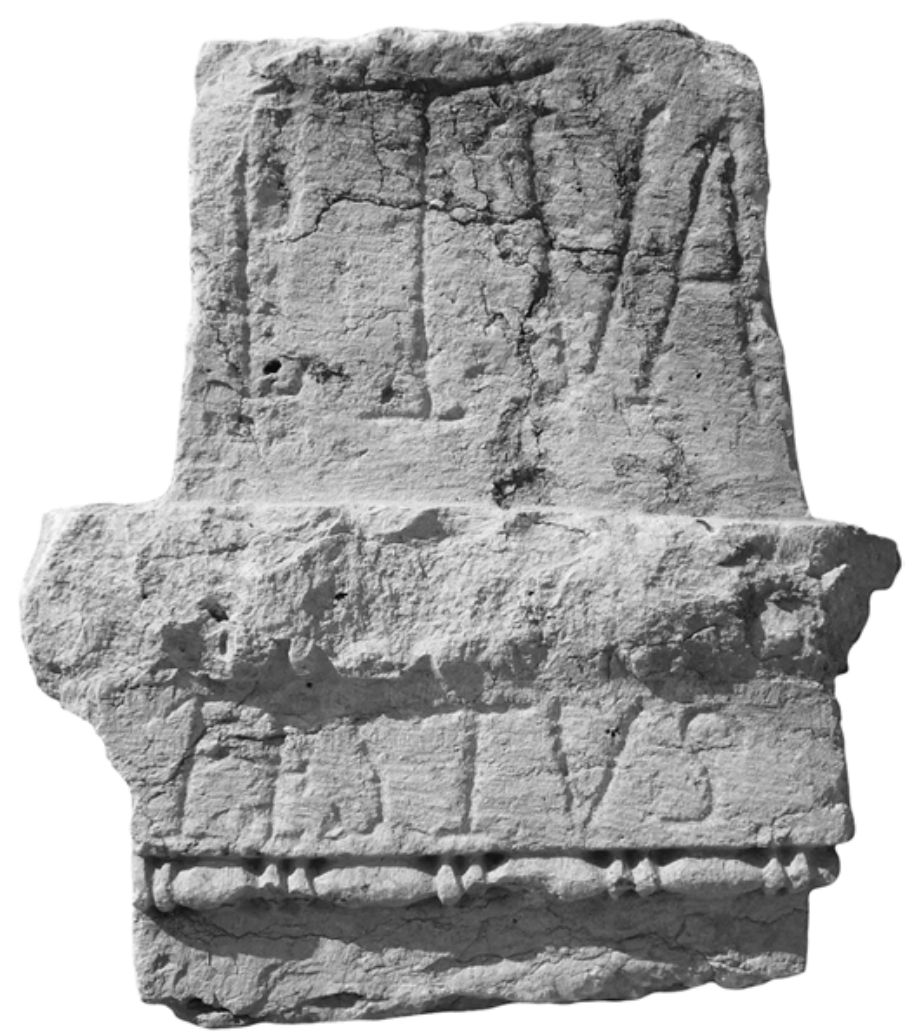

that punctuated the façade (Figs. 4-5). More classical in its presentation around a centred plan architecture, the inscription of the Fountain of Liberalis in Timgad ${ }^{15}$ was placed along the entablature blocks that followed the octagonal plan of the monument (Fig. 6). ${ }^{16}$ The uncertainty about the total number of six or eight inscribed fragments raises a question regarding the layout of these blocks: the location along a road and the choice to present only six inscribed blocks that can be restored positioned to the street side, would have allowed the passer-by to read the entire text without stopping as he walked. 

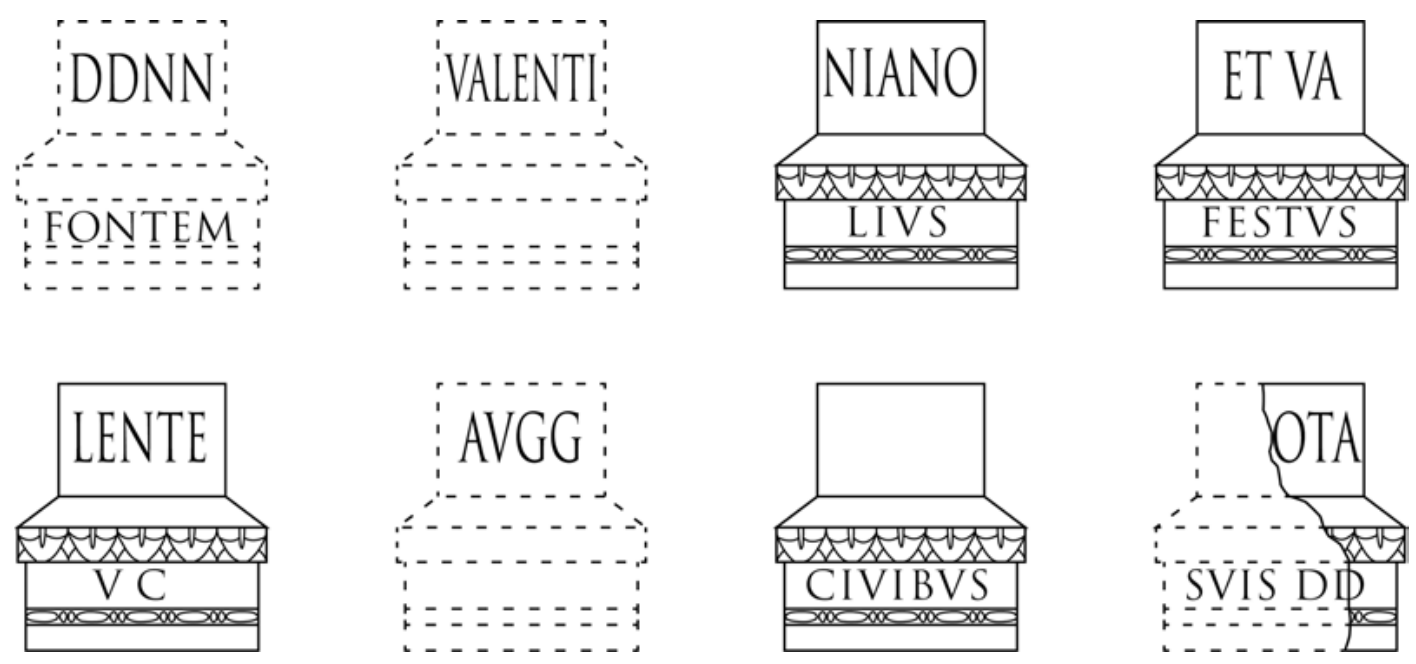

Fig. 5: Sbeitla, Fountain to the southwest of the forum, restitution of the inscribed blocks.

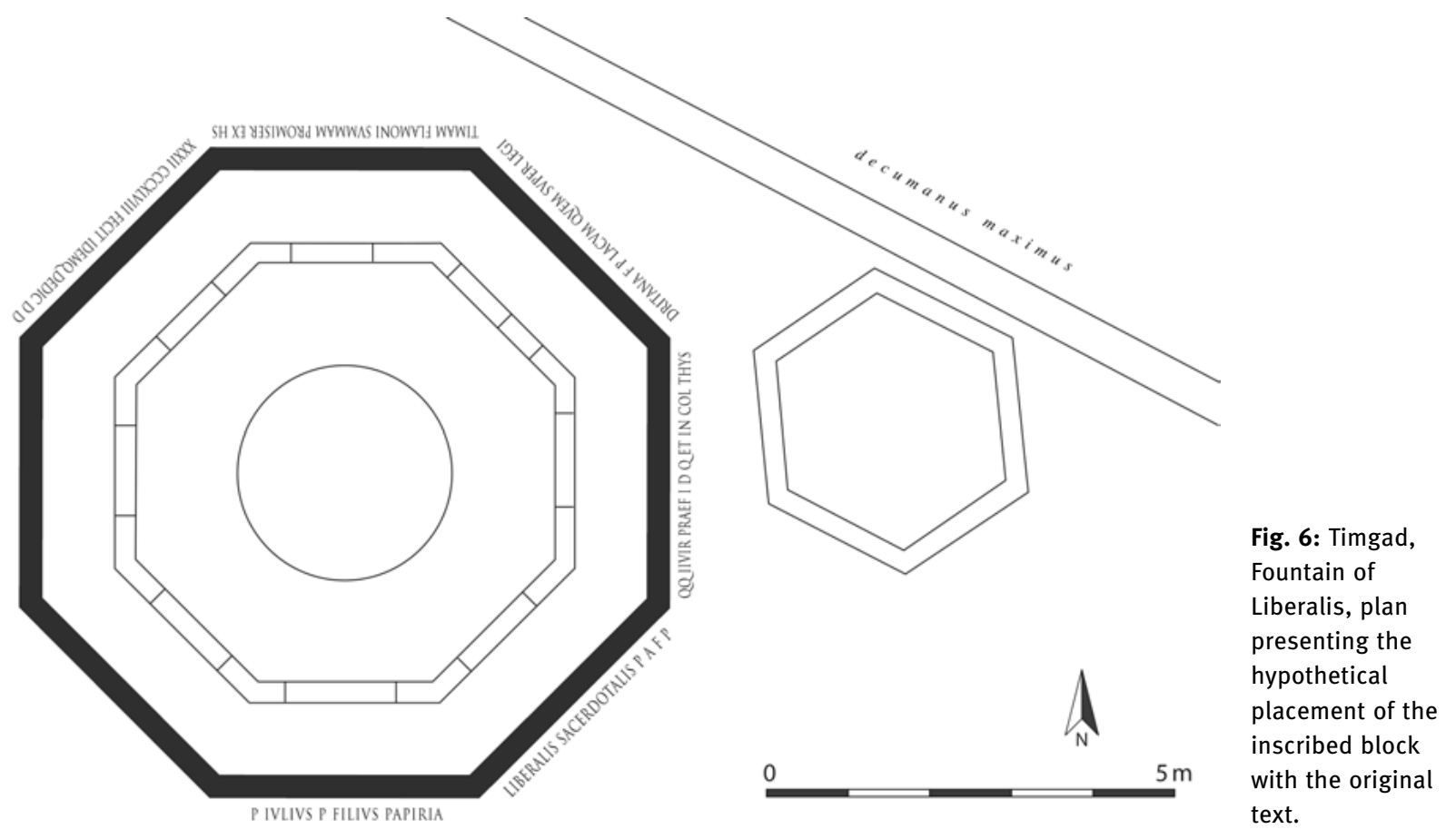

\section{Meeting at the fountain: monuments of daily life}

Roger Ling's suggestion that we should consider the encroachment of public space on a shop for the erection of a fountain as a choice of the owner, because it was likely to benefit his business due to the frequentation around the water point, ${ }^{17}$ raises questions about the people who used these places on a daily basis.

In North Africa, among the terracotta figurines of Carthaginian necropolises, a woman carrying an amphora on her shoulder was discovered, probably a servant according to the unbelted 
tunic she is wearing. ${ }^{18}$ More generally, we have evidence of aquarii in Rome, who could be public or household slaves, ${ }^{19}$ as well as free men selling their services to carry water to the insulae. ${ }^{20}$ However, they could also be members of the water service, and it is difficult to distinguish them from the supposed water carriers. ${ }^{21}$ The situation in Rome is very particular in many respects; nevertheless these individuals are attested elsewhere, such as the collegium of aquarii mentioned in an inscription of Venusia: ${ }^{22}$ whether water sellers or people committed to the maintenance of water monuments, it is possible to consider their presence in African territory. ${ }^{23}$ The aquarii, in Rome as elsewhere, could not only draw water from certain large fountains, but also take over their maintenance. Were they fully committed to this role? There was probably no cura aquarum service in small towns that could not afford it. ${ }^{24}$ The duumviri or aediles were responsible for this task, which could be assigned to a person on an ad hoc basis, such as L. Terentius Romanus in Dougga. ${ }^{25}$ Municipal staff were also responsible for the maintenance of fountains and other public monuments. Sewer maintenance was also the responsibility of the public authorities, ${ }^{26}$ but private individuals could not be prevented from repairing and maintaining their pipes themselves. ${ }^{27}$

Roman women also went to the fountain, as Horace testifies in his Satires, offering a very vivid description of a daily scene. ${ }^{28}$ Much later in Constantinople, ${ }^{29}$ during the drought of $562-$ 563 , testimonies of fights and even murders, ${ }^{30}$ or the crowd rushing around the fountains after damage caused to the aqueduct, ${ }^{31}$ confirm the role of these monuments in supplying the population and the convergence point they constituted.

A place of passage and an important meeting point due to its utilitarian function, a fountain could also be a quiet space in the heart of the city. However, there are few indications to validate this role of monumental fountains in North Africa. None, for example, is associated with any benches, at least in stone. ${ }^{32}$ Perhaps such arrangements existed in perishable materials as in the exedras, ${ }^{33}$ which were equipped with wooden benches. The monumental fountains of semicircular plan, commonly known as 'semi-circular exedra nymphaeum' - terminology which Sal-

18 Chérif 1988, 10 fig. 11.

19 Aquarii could be serui publici attached to the water service, whose existence is still attested in late antiquity: Weiß 2004, 117-122; Lenski 2006, 345 f. 348. Eighteen quotes are to be found in Frontin. aq.

20 See Bruun 1991, $108 \mathrm{f}$. for quotations of the term, in particular Iuv. 6, 332; Bruun 1997, $140 \mathrm{f}$.

21 Bruun 1991, 190-193.

22 CIL IX, 460.

23 Marano 2015, $152 \mathrm{f}$. considers that their presence in all the cities of the empire should not be overestimated, contra Lenski 2006, 345 and Biundo 2008, 169.

24 A recent study proposed to identify such a service in Vienne (France) based on the stamp of a lead pipe: Rémy et al. 2011.

25 AE 1966, 512 = Dougga 37. The man is honoured ob aquae curam but does not bear in the inscription the title of curator aquae, which is found neither in North Africa nor in Gaul: Corbier 1984, 272 n. 200. 201; Ronin 2015, 4042.

26 Dig. 43, 23, 1, 3. Little is known about the officers who conducted this maintenance; perhaps they were slaves and prisoners: Wilson 2000, 170.

27 Dig. 39, 1, 5, 11; 43, 23, 1, 7. About these questions, see Saliou 1994, 166; Ronin 2015, 79-82. 200-204.

28 Whatever [the poet] has once scribbled on his sheets he will rejoice to have all know, all the slaves and old dames as they come home from bakehouse and pond. Hor. Sat. 1, 4, 36-38: et quodcumque semel chartis illeuerit, omnis / gestiet a furno redeuntis scire lacuque / et pueros et anus. (translation by Fairclough 1961). See Magalhães de Oliveira 2012, 105-107 on the fountain as a privileged meeting place for the neighbours and an essential link in the local social networks that characterized the life of the neighbourhoods, especially the most popular ones.

29 Crow 2012, 129.

30 Theoph. AM 6055.

31 Procop. Arc 26, 23.

32 Regarding the benches in the public space of Pompeii, see Hartnett 2017, 195-223, in particular $220 \mathrm{f}$. concerning the lack of bench construction by civic authorities and the lack of urban 'comfort' in the modern sense.

33 On the origin and meaning of the term, with bibliographical, literary, epigraphic, and archaeological references, see Settis 1973, 662-682. 


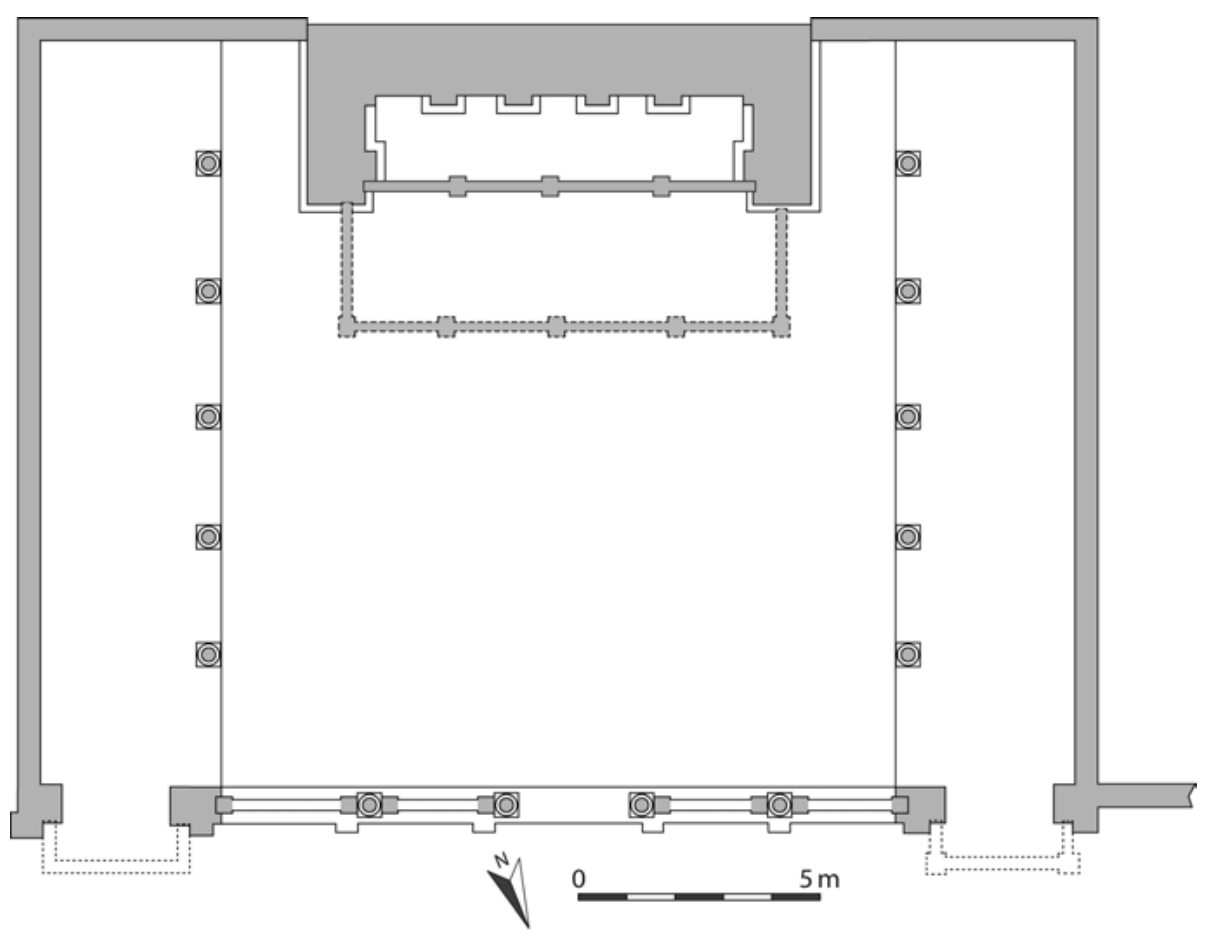

Fig. 7: Sbeitla, Northern Fountain, plan of the original construction presenting the hypothetical draw basin. Two porticoes frame the courtyard.

vatore Settis pointed out is unsuitable and incorrect, recalling the existence of rectangular exedras - were certainly suitable to accommodate passers-by for a moment of rest, but this function can hardly be attributed to them with certainty: no specific arrangement for the Great Nymphaeum of Lepcis Magna, ${ }^{34}$ for instance, would support this assumption. On the other hand, fountains associated with a portico were more suitable to accommodate people, such as the hemicycle-fountain of Cuicul under the northern portico of the Forum des Sévères ${ }^{35}$ or the Northern Fountain of Sbeitla framed by two porticoes defining a courtyard (Fig. 7). ${ }^{36}$ Moreover, the orientation of the fountain could have a significant effect, considering the shadow that a high façade could cast: the nymphaeum of Sbiba ${ }^{37}$ presented its façade to the north; the nymphaeum of $\mathrm{Chem} \mathrm{tou}^{38}$ opened to the east, the Great Nymphaeum of Lepcis Magna to the west. Nevertheless, it is difficult to conclude that there was a deliberate choice for the placement of fountains, as the orientations are very diverse and the technical and urban planning constraints were already very numerous and essential. It is worth mentioning that on the platform of the Lacus of Terentius in Dougga a probable 'game' was engraved on the slabs, just as in Sbeitla where there was reported a 'game of marbles' on the pavement of the Northern Fountain, ${ }^{39}$ distractions that could be compared to those known at the Timgad forum: $:^{40}$ the esplanade was thus willingly the place for a relaxing moment and not just for passing.

34 Letzner 1999, 410 f. no. 255; Ward-Perkins 1993, 79-87; Sandoz 2008; Lamare 2019, 343-346 no. 27.

35 Ballu 1921, 49; Aupert 1974, 95; Letzner 1999, 345 no. 136; Kleinwächter 2001, 100 f.; Lamare 2019, 321f. no. 14.

36 Cèbe 1957, 170 pl. 3; Lamare 2017.

37 Letzner 1999, 396 no. 232; Lamare 2019, 365-367 no. 40.

38 Aupert 1974, 93; Letzner 1999, 487 no. 396; Rakob 1993, 7-16; Lamare 2019, 361f. no. 38.

39 Poinssot - Lantier 1922, p. CXVII n. 7. The holes of a marble game, according to the authors, were located along the entrance portico in the first intercolumniation on the left.

40 Boeswillwald et al. 1905, 19-21. 27 (the hopscotch). 29-31. 


\section{Fountains as way stations: an element of urban agency}

Fountains were not the only buildings to feature on their façades the honorary or commemorative inscriptions that were omnipresent in the city. Nevertheless, fountains constitute a category of buildings apart in the townscape that should be analysed from the point of view of the urban context..$^{41}$ William MacDonald classified fountains as one of the city's 'way stations', along with exedras and porticoed courtyards. Like arches, they were urban breaks, marking the city's framework, but conversely, they were located along the axes and not across them. These monuments, designed for people to stop and rest and offering a quiet space away from the hustle and bustle of the street, were 'a species of half-building, their volumes, partially defined, joining directly with those of contiguous streets and squares, ready to receive diversions from the traffic alongside'. ${ }^{42}$ Francesco Tomasello has already criticised this approach, arguing that it is a simplistic view which belittles the dialectics and inventiveness of the urban project as a whole, where the richness of the solutions recalls the particularity of the projects and perspectives, and the relationship of the monument with the urban context. The example he gives of the Lacus of the theatre in Lepcis Magna ${ }^{43}$ is quite enlightening: its construction solved the problem of the view of the two orthogonal and converging streets dominated by the massive presence of the stage body. The fountain formed a cut-off panel and its oblique lateral returns finalised its organic connection with the theatre; the emphasis of the composition was placed on the large niche that gave depth and thus resolved the perspective of the crossroads. ${ }^{44}$

Thus, fountains are indeed way stations, breaks in the urban landscape, especially when they are part of defined spaces, such as small plazas. The fountain near the northern baths in Volubilis blocked and embellished a path inaccessible due to the presence of the aqueduct and of an ancient tumulus, and thus closed a kind of square, later structured by the arch of Caracalla. In Sabratha, the so-called 'Flavius Tullus Fountain' was the only building that occupied the place preceding the Antonine temple: it was thus highlighted on this large esplanade, while being placed on the side so as not to obstruct the view of the temple's façade (Fig. 8). Nevertheless, fountains are buildings in their own right, well linked to the surrounding monuments and whose location has not only been defined by the need to fill an urban 'void'. Moreover, the function of fountains as resting places, as for exedras, should not be overestimated. Their Naiads babbling through all the streets of Rome, wrote Propertius, ${ }^{45}$ while Pliny the Younger evoked the most pleasing murmur of a little fountain in a room of his Tuscan villa, ${ }^{46}$ but the largest buildings would have made such a whirlwind noise as to make the voice rise, something that everyone can experience today in front of the Trevi Fountain in Rome. At this point, it is necessary to mention Sidonius Apollinaris, who indicates that in the baths, so difficult is it to exchange words intelligibly, owing to the roar of the falling stream. ${ }^{47}$ However, answering the question of levels of fountain noise can only be done if we know the flow of water and the way in which

41 For examples in Northern Italy, see Kreuz, this volume.

42 MacDonald 1986, 99-103.

43 Letzner 1999, 482 no. 384; Tomasello 2005, 37-57; Lamare 2019, 350-353 no. 30.

44 Tomasello 2005, $191 \mathrm{f}$.

45 Prop. 2, 32, 15: et leuiter nymphis tota crepitantibus urbe (translation by Butler 1962).

46 Plin. Ep. 5, 6, 23: Fonticulus in hoc, in fonte crater, circa sipunculi plures miscent iucundissimum murmur (translation by Melmoth 1961). Vendries 2014, $213 \mathrm{f}$., insists on the necessity to take into consideration this noise of water in order to imagine the atmosphere of Roman gardens, and recalls, moreover, that Latin literature generally associates it with the chirping of birds and therefore with an element of appeasement.

47 Sid. Apoll. Epist. 2, 2, 9: quia prae strepitu caduci fluminis mutuae uocum uices minus intelliguntur (translation by Anderson 1956). 


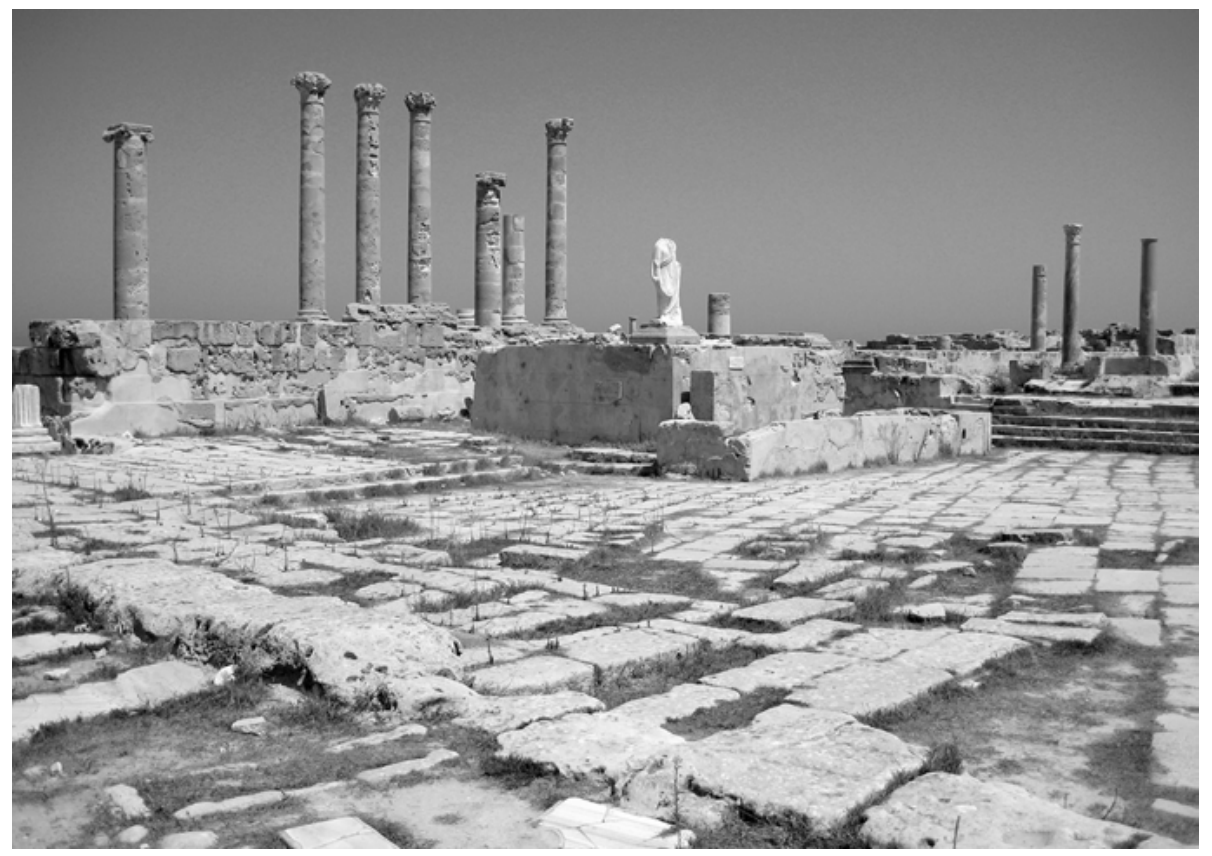

Fig. 8: Sabratha, so-called 'Fountain of Flavius Tullus' on the esplanade in front of the Antonine temple, the access stairs of which are visible on the right.

the pipes were laid out: ${ }^{48}$ literary sources clearly show that perceptions were different according to context. ${ }^{49}$

Finally, unlike forums, markets or theatres, which are 'closed' monuments that present their decoration only when one enters their interior space, fountains are among the buildings that display their figurative ornamentation along the streets, also including arches, tetrapylons, and gates. However, two specific features distinguish them from the latter types. First, as mentioned, fountains were placed along or at the intersections of roads and not across them. Their situation generally left a sufficient distance to highlight their façade and the sculpted decoration that was used. ${ }^{50}$ The fountains of Althiburos and Volubilis, but also of the Hercules nymphaeum of Lepcis Magna, with their right-angled basins that occupied both sides of the intersection where they were located, exemplify the buildings' integration into the urban landscape. A study from this perspective has been carried out on African triumphal arches, in which the author was interested in the mechanics of vision, the object and its connection with space, trying to determine if they represented a focal point of the urban landscape. ${ }^{51}$ The second point is the dynamic aspect that characterizes fountains. Cecelia Feldman Weiss adopted a phenomenological approach to the urban landscape to investigate the Nymphaeum Traiani at Ephesus. ${ }^{52}$ Water flowing through the nymphaeum and into the city, from the central mouth to the basin, from the overflow over the parapet to the sewer, produced visual, auditory, and sensory effects. These effects, the result of a human creation, were sought and accentuated by the location of the fountain, clearly visible along the Curetes Street, highlighted by the interruption of the colonnade at its height. A whole 'archaeology of the senses' is thus developing around fountains and water games more generally, as Dylan Rogers has shown, particularly from literary sources. ${ }^{53}$

48 Richard 2012, 161 considers that most of the monumental fountains had a reduced flow and that the noise of the eddies should not be exaggerated. The discussion is extended in Richard 2016.

49 See Rogers 2018, 81-85 for an overview of sources evoking the noise of water games. Aldrete 2014, 50 restores to Rome a sound environment marked by the murmur of the water from the fountains.

50 Lamare 2019, 145-170.

51 Youcef Chennaoui presented his study entitled 'Les arcs de triomphe en Algérie antique: histoire, forme et structures' during the conference 'L'Africa Romana XIX' (Sassari, 16-19. 12. 2010). The paper has not been published in the conference proceedings.

52 Feldman Weiss 2010, 66-69.

53 Rogers 2018, 81-85 and methodological overview 4-10. See also Dylan Rogers, this volume. 
Fountains, and water more broadly, thus contribute to the aesthetics of the urban landscape but, beyond that, to the permanence of a prosperous situation. ${ }^{54}$ The inscriptions testify to two major motivations in the construction of fountains, which could be referred to as amonitas and utilitas..$^{55}$ Thus in Abbir Maius, a fountain was built ad usum utriusque aquae, probably at the end of the two branches of aqueducts from which it discharged the water into the city, but also as an ornamentum ciuitatis, participating in the city's decoration..$^{56}$ In Thysdrus, the emphasis is on water availability, per plateas lacubus inpertita, divided into fountains or basins throughout the city. ${ }^{57}$ Hydraulic installations also refer to the salus. An inscription from Althiburos mentions the collection of sources carried out beneficia etiam ornamentum moenibus et salutem ciuibus. ${ }^{58}$ This idea can be found in the famous inscription of Tiddis, which refers to water supply works, around 250-251. ${ }^{59}$ The words ad salutem populi would, according to François Jacques, be much more than a reference to the 'good health', salus also meaning the preservation of an established situation, coherent with the idea of a restoration of hydraulic structures.

\section{Fountains in the late antique city}

\section{Keeping the fountains visible: remodelling the urban space}

After the installation of many fountains in cities during the Early Roman Empire, their construction did not stop in late antiquity. In Lambaesis, a nymphaeum was built near the groma of the camp, ${ }^{60}$ perhaps at the end of the $3^{\text {rd }}$ century during a restoration on the occasion of Emperor Maximian's visit. ${ }^{61}$ It is located immediately east of the praetorium, on the south side of the decumanus maximus. Similarly, in Tipasa, the nymphaeum is implanted along the decumanus on the south side. The paving of the road was probably modified during the construction of the fountain: just in front of it, the alignment of the slabs stops and the stones are placed in such a way that they form a circular pattern. ${ }^{62}$

In Timgad and Cuicul, fountains were built along the decumanus and the cardo, but over a portion which had been extended in the $2^{\text {nd }}$ century or the Severan period. Indeed, the Fountain of Liberalis in Timgad is $200 \mathrm{~m}$ from the 'Arch of Trajan', which marks the boundary of the city's earlier urban setting. These suburbs must have developed very early in the $2^{\text {nd }}$ century, and major monuments, such as the temple of the Genius coloniae or the Market of Sertius, located in the western suburb, bear witness to the creation of these districts in a very early period. ${ }^{63}$ Thus, the fountain, built in the third quarter of the $3^{\text {rd }}$ century, was most probably built along an existing road (Fig. 6). The opposite reasoning can give us an idea of the urban topography at that time: it is unlikely that Liberalis would have had such a sumptuous fountain built in an empty or sparsely frequented area, which confirms the idea that this suburb was already urbanized. ${ }^{64}$ In Cuicul, the Fountain of the Tetrarchy ${ }^{65}$ is built in front of the façade of the Great

\footnotetext{
54 Jacques 1983, 207-209.

55 See Schmölder-Veit 2009, 23-25 for a wider analysis on the Western Mediterranean.

56 AE 1993, 1738.

57 CIL VIII, 51 = ILS, $5777=$ AE 2008, 1611.

58 CIL VIII, 1828 = ILS, 5783 = ILTun, 1645.

59 AE 1946, 61 = ILAlg II 1, 3596.

60 Rakob - Storz 1974; Rakob 1979; Lamare 2019, 328 f. no. 17.

61 CIL VIII, 2571 = 18057 = AE 1974, 723a; CIL VIII, 2572 = ILS, 5786.

62 Aupert 1974, 77 pl. 2.

63 Lassus 1966.

64 Lassus 1965, 247 f. suggests that 'thought-out' urban planning was already being projected under the Antonines and continued under the Severan dynasty.

65 Ballu 1921, 66; Lamare 2019, 322-324 no. 15.
} 


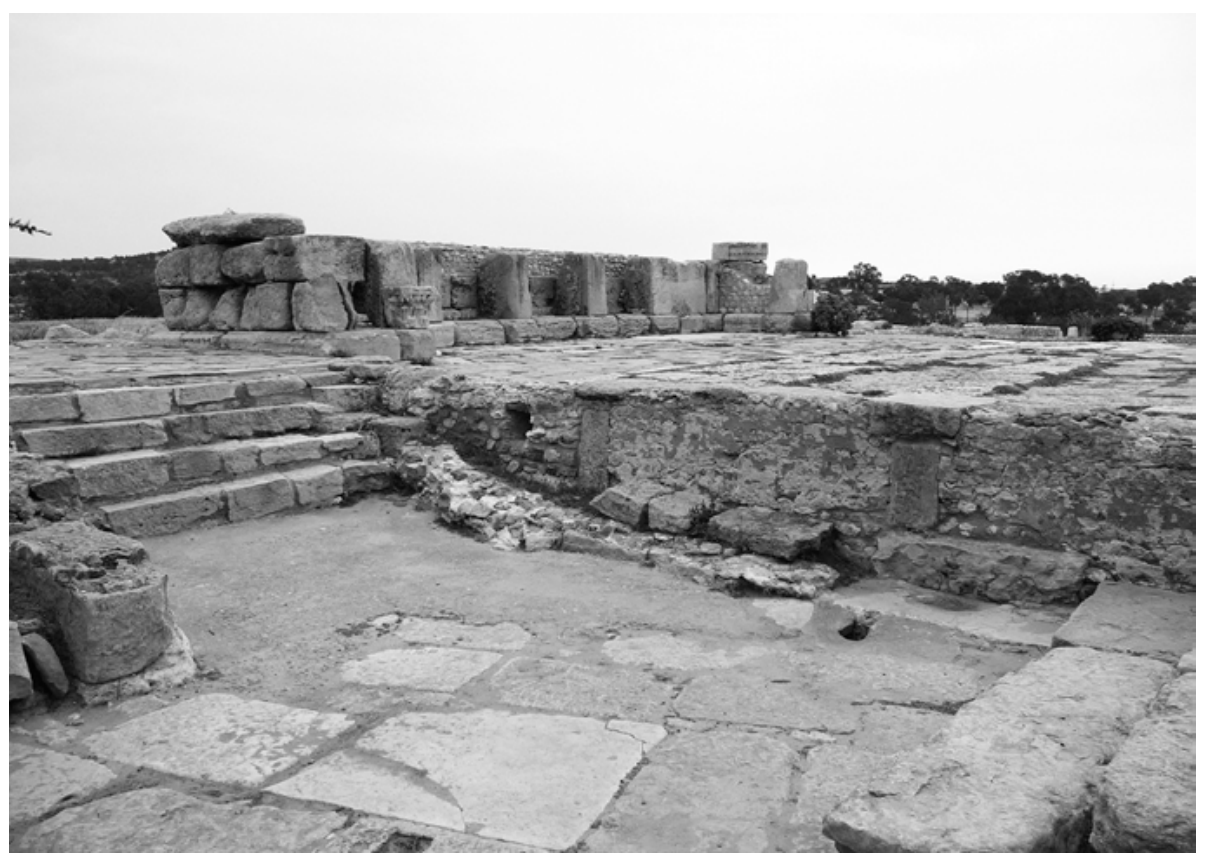

Southern Baths. It obstructs a passage between the baths and a residential area to the south: the traffic has therefore been modified in this area ${ }^{66}$ (Fig. 3).

In Sbeitla, three fountains were built, one of which is dated by a dedication to the years $364-367 .{ }^{67}$ It has been suggested that the other two fountains, because of their similar architecture, were erected at the same time. ${ }^{68}$ Each one was built on a more or less vast plaza. One was located to the southwest of the forum, possibly at the end of a small square overlooking a secondary road. A second was placed near Basilica III, also known as the Basilica of Servus: it was built on a platform placed over the decumanus maximus of the city, which prevented vehicle traffic, but allowed pedestrians to pass through via a set of stairs (Fig. 9). The third one, slightly offcentre, $200 \mathrm{~m}$ north of the capitol, is preceded by a much larger courtyard (about $20 \times 16 \mathrm{~m}$ ) (Fig. 7).

Other fountains, built during the $2^{\text {nd }}$ or $3^{\text {rd }}$ century, have simply been restored and sometimes enlarged. In Macomades, ${ }^{69}$ in $305-306$, it is not known whether the lacus was only restored at the same time as a dated water pipe or whether it was built on that occasion, as we saw in the case of Cuicul. In Lambaesis, the nymphaeum-septizonium was restored twenty years after its construction and the sponsor states that all the decoration was redone, mainly with marble. ${ }^{70}$ Architectural and archaeological studies have shown that a trapezoidal basin was added in front of the Great Nymphaeum of Lepcis Magna, ${ }^{71}$ as well as at the fountain of Mactar, ${ }^{72}$ probably in the $4^{\text {th }}$ century. An inscription from Dougga mentions the addition of a portico in front of a fountain - which is not identified among those known on the site - also during the restoration of the hydraulic system. ${ }^{73}$ In Pheradi Maius, the nymphaeum was built in the
Fig. 9: Sbeitla, Fountain near the Basilica of Servus, view towards the east. In the foreground the decumanus, in the background the platform.

66 An updated plan of the area is published in Février - Blanchard-Lemée 2019, pl. 1.

67 See n. 14. Cèbe 1957; Lamare 2019, 369 f. no. 41.

68 Cèbe 1957, 170 f.; Lamare 2019, 370-372 nos. 42-43.

69 CIL VIII, $4766=18700$.

70 CIL VIII, $2657=18105=$ ILS, $5626=$ AE 1973, 645 .

71 Sandoz 2006, $406 \mathrm{f}$.

72 Bourgeois 1973/1974; Lamare 2019, 353 f. no. 31.

73 CIL VIII, 1490 = 26568 = AE 1904, 122 = ILAfr, 533 = Dougga 43. 
reign of Antoninus. ${ }^{74}$ However, the lack of coherence between the basins and the arcades of the façade suggests that the latter was built in a second phase, perhaps in relation to the largescale repairs of the $4^{\text {th }}$ century, which are mentioned by an inscription. ${ }^{75}$

The situation in other provinces can be compared to that of North Africa. In Asia Minor, two examples of restorations are worth noting. The first is that of the nymphaeum of Side, which under Gordian III underwent several modifications. ${ }^{76}$ The second example is the nymphaeum of Miletus, built in the Flavian period, which was elevated with a third storey and decorated with numerous statuary elements in the $3^{\text {rd }}$ century, under the proconsulate of L. Egnatius Victor Lollianus, dated $242-245,{ }^{77}$ as mentioned on the upper floor inscription. ${ }^{78}$ In the Middle East, there is also evidence of fountain restorations dating back to the Early Roman Empire. In Antioch on the Orontes, the construction of a nymphaeum, perpendicular to the porticoed track, which occupied the northern side of a courtyard, makes sense as part of the reconfiguration of this road, dating from the reconstruction that took place under Justinian's reign. ${ }^{79}$ The NysaScythopolis nymphaeum, built in the $2^{\text {nd }}$ century according to the architectural study, was destroyed and then rebuilt around 400, under the Governor Artemidorus, as part of a citywide building programme, including the redesign of part of the porticoed street along which it stood, and of a bath building. ${ }^{80}$

\section{Building, restoring, and transforming fountains: maintaining monuments and practices}

Do late restorations and constructions indicate a change in the function of the buildings? Andrea Schmölder-Veit uses the name 'Nymphäumsraum' for a type of nymphaeum which she compares to the 'nymphaea a camera' of Norman Neuerburg's typology, and notes that these buildings form a very particular category which has never been highlighted in the existing typologies. These are independent structures, not connected to a public building, sanctuary or house. They are defined by the presence of a covered space or surrounded by porches: thus, the monument could be enclosed or the porches closed by doors. The plan views show much larger buildings, as the monuments were often inserted into existing structures. ${ }^{81}$

It has been suggested that latrines and baths gradually lost their role as places of sociability at a later stage, ${ }^{82}$ although this idea has recently been tempered. ${ }^{83}$ Schmölder-Veit proposes that nymphaea were able to fill this gap by becoming meeting places. Their location at the bottom of small squares and their semi-circular shape or their structure surrounded by porticoes would have been ideal for welcoming a group. The idea is indeed attractive and the examples she presents of Ostia, Ephesus, and Sbeitla are revealing. In Ostia, the nymphaeum of the Bivio del Castro $^{84}$ had a façade more than $26 \mathrm{~m}$ wide at a major junction of the city, along the decumanus maximus. Its late establishment, in the $4^{\text {th }}$ century, as recently confirmed by stratigraphy, took place along a section which was cut off by the façade of a house from the Early Roman Empire.

\footnotetext{
74 Kleinwächter 2001, 190-195; Lamare 2019, 355 f. no. 32.

75 ILTun, 251.

76 Dorl-Klingenschmid 2001, 242-244 no. 106.

77 According to Loriot 1996, 223 no. 16 and not 241-244 as Dorl-Klingenschmid 2001, 215 f. no. 64 indicates.

78 Hülsen et al. 1919, 71.

79 Lassus 1972, 44-52. 125 pl. 69.

80 Tsafrir - Foerster 1997, 95 f. 106-116.

81 Schmölder-Veit 2010.

82 Neudecker 1994, 62-72 quoted by Schmölder-Veit 2010, 113 n. 22; Thébert 1999, 383-388; Thébert 2003, 482 f.

83 Bowes 2010, 52-54.

84 Neuerburg 1965, 179 no. 110; Letzner 1999, 436 no. 309. See the results of recent excavations and the analyses of Lavan 2012, 681-685.
} 
A very large basin then occupied this corner, preceding the façade, giving the crossroads a rich decor. Nevertheless, I would remain more cautious about the interpretation that only because fountains had prestigious architecture, they must have been solely ornamental, based on the width and height of the parapets of the basins that made it impossible to draw water. In Sbeitla, the parapets of the Northern Fountain are indeed quite high and show no signs of wear, which is very surprising. My examination of this building has revealed several elements that suggest that a previous basin existed and provided a source of water. ${ }^{85}$ The catchment basins of the other two fountains on the site have disappeared. ${ }^{86}$ In addition, on all other examples of fountains, whether late antique or not, the parapets of the basins, when preserved, show signs of wear, which is proof that the fountains were still used to draw water, as in Tipasa, Cuicul, and Pheradi Maius. ${ }^{87}$

This is confirmed by the study of Micrasiatic fountains, which show two types of transformations. ${ }^{88}$ The first is the addition of an extra basin in front of the edifice, to facilitate the drawing of water, which was no longer possible due to the height of the original parapet. Sometimes, this basin has been reduced in size, probably due to the decrease in water supply from the aqueduct. The second type of transformation is the perforation of the balusters of the basin parapet. These small holes allowed a stream of water to flow, underneath which a container could be placed, a technique that was easier than bending over to draw from the pool. Sometimes, traces of snagging near the orifice suggest the presence of a bronze waterspout, as in Sagalassos. ${ }^{89}$ In North Africa, at Lepcis Magna, a basin was added in front of the Nymphaeum of Hercules before the middle of the $4^{\text {th }}$ century, at a time when part of the original drawing basin had been abandoned. ${ }^{90}$ Two holes drilled in the balustrade poured water into this basin, which was accessed by slabs that formed a step. There is also a small monolithic tank buried in front of the basin of the Fountain near the Basilica of Servus in Sbeitla, which could be a late addition of the same type (Fig. 10).

Some larger holes may indicate the presence of pipes that used to supply other buildings. The example of a fountain in Pergamon ${ }^{91}$ is a good comparison for the arrangements of the Northern Fountain in Sbeitla. On the latter, three large holes are visible on the southern parapet of the basin, the only one left. One could assume the presence of water redistribution pipes in other parts of the city. Indeed, the construction of fountains in the second half of the $4^{\text {th }}$ century indicates that the water supply was effective at that time, at least for the supply of the three fountains. Also, this supply could have been maintained until the following centuries, when the original network in other parts of the city had potentially declined. Thus, the fountain could, at that time, have been used as a distributing device within the city. ${ }^{92}$

In Asia Minor, many buildings were transformed into fountains in the late antique period. ${ }^{93}$ It is enough to mention the most famous of them, the Library of Celsus in Ephesus, transformed at the end of the $4^{\text {th }}$ or the beginning of the $5^{\text {th }}$ century by the addition of a basin in front of its monumental façade. ${ }^{94}$ There are no comparable examples to my knowledge in North Africa, although it would be necessary to study in detail the various urban water developments that might reveal such transformations. Nevertheless, this absence can be explained by the chronological shift in the construction of fountains between Asia Minor and North Africa: African foun-

\footnotetext{
85 Lamare 2017, 99-102.

86 See n.67.

87 Cf. Lamare 2019, $236 \mathrm{f}$.

88 Jacobs - Richard 2012, 43-54.

89 Jacobs - Richard 2012, 50 fig. 27.

90 Tomasello 2005, 57-111; Lamare 2019, 347-350 no. 29.

91 Jacobs - Richard 2012, 48 f. fig. 26.

92 Lamare 2017, 107-111.

93 Jacobs - Richard 2012, 12-22.

94 IK-Ephesos, 5110. 5115; Dorl-Klingenschmid 2001, 191 no. 29.
} 
Fig. 10: Sbeitla, Fountain near the Basilica of Servus. In the centre, the slot where the parapet's slabs originally stood; on the left, the small tank directly below the original basin.

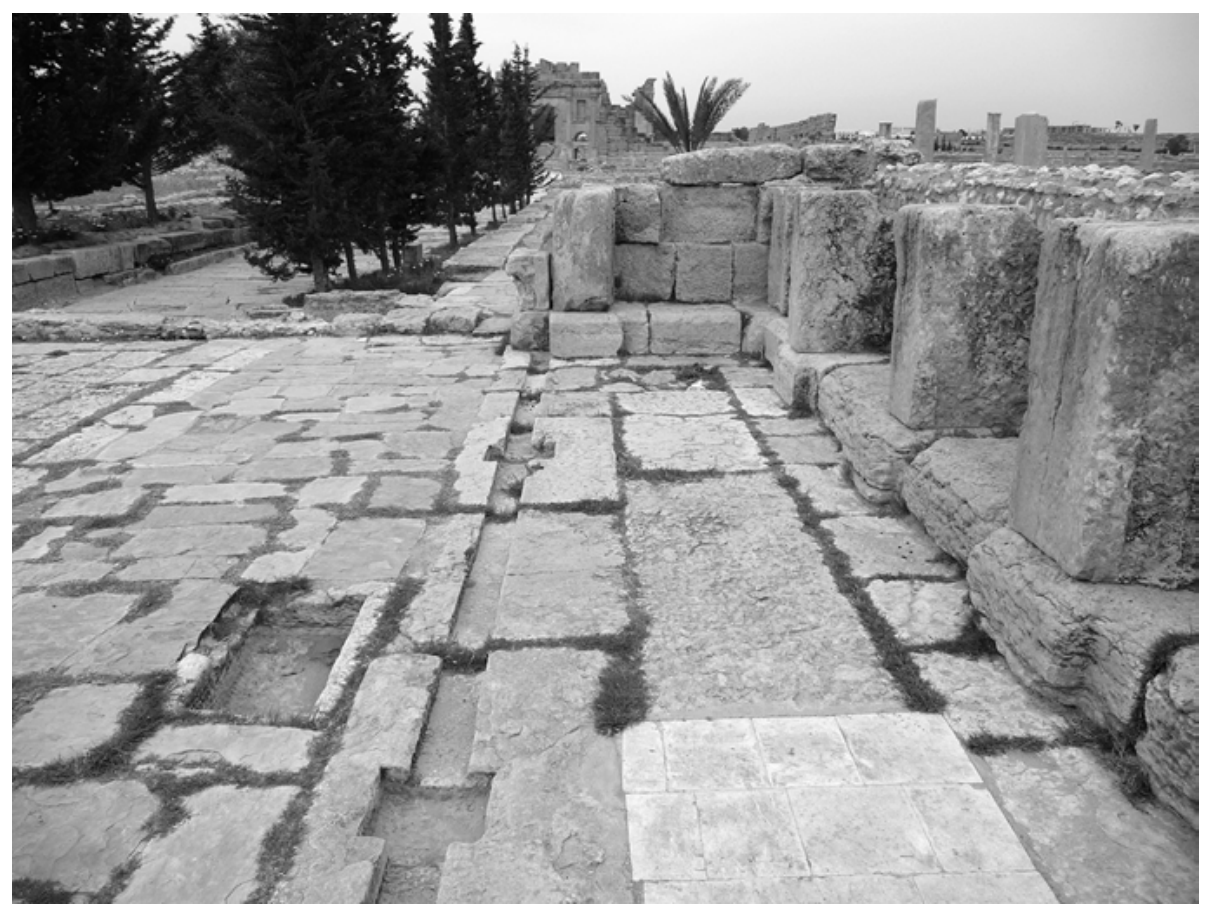

tains built during the Early Roman Empire were restored until a very late period, but many monuments were not built before the $3^{\text {rd }}$ and early $4^{\text {th }}$ centuries; in contrast, the construction of Micrasiatic fountains was active until the first two decades of the $3^{\text {rd }}$ century and few were newly built after this date. ${ }^{95}$

\section{Clear and abundant water: fountains as a metaphor of urban aesthetics and permanence}

These restorations, or even new constructions, should open the way for a discussion on late antique urban planning. The question has been debated about North Africa through the case of Sbeitla. Jean-Pierre Cèbe proposed that the construction of fountains should be an indication of an extension of the city in the $4^{\text {th }}$ century. ${ }^{96}$ This hypothesis was rejected by Noël Duval, who pointed out that the three monuments were located in the uniformly planned area, arguing that their construction cannot be explained by an extension of the city or a population increase, but rather represented a change in the supply system, a transformation of the city centre into a residential area, or simply a 'taste of the time' for nymphaea. ${ }^{97}$

Since Claude Lepelley's research on North African cities, initiated by the earlier work of Paul-Albert Février, we know that there was no break in the maintenance of the urban environment after the $3^{\text {rd }}$ century and that it remained one of the major concerns of the local elite, both through constructions and restorations. ${ }^{98}$ The fountains erected after the Severan period were all built in already developed parts of the city. Luke Lavan pointed out that in Ostia the construction of new public squares was exceptional in the late period, compared to other provinces. ${ }^{99}$ On the other hand, he indicated that the attention paid to the pedestrian function of the decu-

95 Jacobs - Richard 2012, 9-12.

96 Cèbe 1957, 204.

97 Duval 1964, 94-96.

98 Lepelley 1979; Lepelley 1981.

99 Lavan 2012, 686 f. 
manus was a characteristic feature of Late Antiquity, an example being the construction of arcades and colonnades, even more frequent in the eastern Mediterranean than in the west. In North Africa, in addition to the Northern Fountain of Sbeitla or that of Dougga which is known by an inscription, ${ }^{100}$ whose porticoes could offer passers-by a rest area along one of the city's major avenues, the Fountain near the Basilica of Servus in Sbeitla illustrates this emphasis on the pedestrian use of urban roads: the esplanade in front of the fountain was positioned over the decumanus, cutting off the passage for vehicles, but allowing free circulation for pedestrians by means of stairs (Fig. 9). We must think of the many activities that could take place in the streets, squares, or under the porches of the classical and late antique Mediterranean cities. I have already mentioned a game carved on the slabs of the Lacus of Terentius in Dougga and the one identified along the entrance portico of the Northern Fountain of Sbeitla. It is necessary to take into account not only the building, but the space as a whole, in order to be able to build a topography of the human activities of the late antique city: fountains, because of their ornamental and functional role, are able to contribute to this approach. ${ }^{101}$ Nevertheless, regarding the aesthetic impact, if the choice of this location results in the blocking of a traffic lane, it places the fountain in the perfect alignment of a secondary cardo.

On the other hand, Lavan brings up the point that the development of main roads has often been to the detriment of secondary streets, even more frequently in the East. Examples of late antique African fountains were located along the main roads, as in the Early Roman Empire. The Fountain of Liberalis in Timgad and the Nymphaeum of Tipasa are both found along the decumanus maximus; in the latter case, if the apse located on the edge of the decumanus did not offer a perspective on this main road, the probable redesign of the pavement, creating a circular pattern, facing the building, would have enhanced its appearance and staged its decoration. The same applies to the Fountain of the Tetrarchy in Cuicul, situated along the main road going South and which, at the same time, obstructed an alley between the Great South Baths and the House of Bacchus. Its location between these two buildings, at the level of a slight change in the axis of the street, however, allowed the fountain to be seen when coming from the south and the eastern district (Fig. 3), but also to be easily accessible from the portico of the Great Baths.

Fountains reflect a willingness to maintain a certain degree of ornamentation in the city, but they are not a sign of particular wealth or demographic and urban expansion. One will recall the imperial constitution which recommended the construction of a portico at the front of bath buildings in order to increase the beauty of the city. ${ }^{102}$ In fact, an aesthetic concern persists until a very late period, a concern that could be satisfied by the construction and restoration of monumental fountains, whose ornamental role must not be neglected. Indeed, while it is difficult to analyse the visual aspect of late antique African fountains, due to the lack of examples and detailed architectural studies, the textual sources do express the meaning that was intended to be given to these monuments.

An interesting aspect mentioned in the inscriptions is that of water quality and its availability to users. The emphasis in the texts is on the opposition between the old and corrupt condition of the pipe or fountain and the remedial action that restored its original appearance and use. At Lemellef, ${ }^{103}$ reference is made to the water from the spring that multo tempore deperierat while restoration has made it abundans again in the fountain. At Dougga, ${ }^{104}$ the conduct which, ruined by obsolescence, could no longer ensure the flow of water, was restored to its original

100 See n.73.

101 Approach suggested by Lavan 2003. One could propose to develop a 'topography of sociability' in the classical and late antique city.

102 Cod. Theod. 15, 1, 50.

103 CIL VIII, $8809=$ ILS, $5785=$ AE 1908, 30.

104 CIL VIII, $1490=26568=$ AE 1904, $122=$ ILAfr, $533=$ Dougga 43. 
function with the nymphaeum which discharged water for the needs of the city (in usum ciuitatis). The quality of the water is mentioned in an inscription from the region of Guelma, ${ }^{105}$ where a pool contained stagnant water (aqua pigra) which, through the work carried out, has become abundant again. In an inscription from Tunis, ${ }^{106}$ the two aspects mentioned are linked: the lacus sordidus has been renovated so that water abounds again for users. It is a rather similar reference to the three inscriptions of Rome, dated 391, whose almost similar form recalls that the prefect of the city, Flavius Philippus, had restored the nymphium sordium to its original state. ${ }^{107}$ The same rhetorical process is used by Paulinus of Nola who describes, in carmen 21, the old state of the aqueduct and the return of the flow to supply the cities of Abella and Nola. ${ }^{108}$

\section{Conclusion}

Fountains were located in prominent locations in the city, on squares, along main roads, or at major intersections, for several technical and practical reasons. Furthermore, the highlighting of these buildings is explained by the willingness of the imperial or private sponsors to represent themselves and to display the benefits they offered to the city. In the context of the simultaneous construction of a water supply and a fountain, the latter symbolises the durability of the water now brought to the city; in the context of a major urban planning programme, it is through its architecture and decoration, capable of glorifying a person and his entourage, that the installation of the fountain is justified, playing with urban perspectives.

The marks of use on the basins testify to how the availability of water was facilitated by the strategic location of the monumental fountains. They constituted important places of meeting and sociability, where people would encounter each other when coming to draw from them, as in the case of small street fountains. As such, their interaction with residential districts and craft workshops should be studied further, on sites whose topography is sufficiently documented.

Beyond the $3^{\text {rd }}$ century, constructions and restorations continued. Fountains, far from being merely decorative, continued to be essential elements of the water distribution system. Although the installation of the fountains was more dependent on an existing hydraulic network, the buildings remained located in the centre of cities. These constructions in the late antique period, documented at least until the mid- $4^{\text {th }}$ century in North Africa, do not necessarily mean the development of new districts, but do imply, on the other hand, redevelopments that may be linked to adaptations of the supply network.

Thanks to a study focused on a particular type of building, here the fountain, considering its layout, its decoration, its primary function and the multiple uses that it could have, and the multiple activities that could take place there, it is possible to contribute to the discussion on urban sensory archaeology. ${ }^{109}$ It behoves us to reinterpret the uses to which certain places and buildings were put and to distance ourselves from the traditional connections between typology and function. In this way, it will be possible to renew our understanding of the ancient city and to comprehend its agency as well as all its sensory perceptions and subtleties.

105 CIL VIII, 5335 = ILS, 5730 = ILAlg I, 256.

106 AE 1955, 55.

107 CIL VIII, 1728a; CIL VIII, 1728b; CIL VIII, 31912.

108 Paul. Nol. Carm. 21, 751-753, 781-784, 799-815; Herbert de la Portbarré-Viard 2013, 214-218, 228 f.

109 Haug - Kreuz 2016. 


\section{Illustration Credits}

Fig. 1: Photo by Nicolas Lamare, 2009.

Fig. 2: drawing by Nicolas Lamare, after Janon 1973 fig. 17 and CIL VIII, 2657-2659.

Fig. 3: drawing by Nicolas Lamare.

Fig. 4: Photo by Nicolas Lamare, 2010.

Fig. 5: drawing by Nicolas Lamare, after Cèbe 1957 fig. 4.

Fig. 6: drawing by Nicolas Lamare, after Boeswillwald et al. 1905 fig. 149.

Fig. 7: drawing by Nicolas Lamare, after Cèbe 1957 pl. III.

Fig. 8: Photo by Sasha Coachman, 2009 (CC BY-SA 3.0).

Fig. 9: Photo by Nicolas Lamare, 2010.

Fig. 10: Photo by Nicolas Lamare, 2010.

\section{Bibliography}

\section{Primary sources}

Anderson 1956: W. B. Anderson, Sidonius Apollinaris 1, Poems, Letters, Books I-II with an English Translation (London 1956).

Butler 1962: H. E. Butler, Propertius with an English Translation (Cambridge 1962).

Fairclough 1961: H. R. Fairclough, Horace Satires, Epistles and Ars poetica with an English Translation (Cambridge 1961).

Melmoth 1961: W. Melmoth, Pliny Letters with an English Translation (London 1961).

\section{Secondary literature}

Aldrete 2014: G. S. Aldrete, Urban Sensations: Opulence and Ordure, in: J. P. Toner (ed.), A Cultural History of the Senses in Antiquity, The Cultural histories series (London 2014) 45-67.

Aupert 1974: P. Aupert, Le nymphée de Tipasa et les nymphées et "septizonia” nord-africains, CEFR 16 (Rome 1974).

Ballu 1921: A. Ballu, Ruines de Djemila (antique Cuicul) (Algiers 1921).

Balty 1972: J.-C. Balty, Apamée 1969-1971, in: Actes du colloque Apamée de Syrie. Bilan des recherches 19691971, Bruxelles 15-18 avril 1972 (Brussels 1972) 15-31.

Biundo 2008: R. Biundo, La gestion publique de l'eau: finances municipales et centre du pouvoir à l'époque impériale, in: E. Hermon (ed.), Vers une gestion intégrée de l'eau dans l'empire romain, Actes du colloque international, Université Laval, octobre 2006 (Rome 2008) 163-174.

Boeswillwald et al. 1905: E. Boeswillwald - R. Cagnat - A. Ballu, Timgad: une cité africaine sous l'empire romain (Paris 1905).

Bourgeois 1973/1974: C. Bourgeois, Les eaux de Mactar (Tunisie). Essai de reconstitution d'une fontaine monumentale, Karthago 17, 1973/1974, 185-194.

Bowes 2010: K. D. Bowes, Houses and Society in the Later Roman Empire (London 2010).

Bruun 1991: C. Bruun, The Water Supply of Ancient Rome. A Study of Roman Imperial Administration (Helsinki 1991).

Bruun 1997: C. Bruun, Acquedotti e condizioni sociali di Roma imperiale: immagini e realtà, in: La Rome impériale: démographie et logistique, Actes de la table ronde, Rome 25 mars 1994, CEFR 230 (Rome 1997) 121-155.

Cèbe 1957: J.-P. Cèbe, Une fontaine monumentale récemment découverte à Sufetula (Byzacène), MEFRA 69,1, 1957, 163-206, DOI: 10.3406/mefr.1957.7416.

Chérif 1988: Z. Chérif, Le costume de la femme à Carthage à partir des figurines en terre cuite, Africa 10, 1988, 7-18.

Corbier 1984: M. Corbier, De Volsinii à Sestinum. Cura aquae et évergétisme municipal de l'eau en Italie, REL 62, 1984, 236-274.

Crow 2012: J. Crow, Water and Late Antique Constantinople, in: L. Grig - G. Kelly (eds.), Two Romes. Rome and Constantinople in Late Antiquity, Oxford studies in Late Antiquity (Oxford 2012) 116-135.

Dorl-Klingenschmid 2001: C. Dorl-Klingenschmid, Prunkbrunnen in kleinasiatischen Städten. Funktion im Kontext, Studien zur antiken Stadt 7 (Munich 2001). 
Duval 1964: N. Duval, Observations sur l'urbanisme tardif de Sufetula (Tunisie), CahTun 45/46, 1964, 87-103. Feldman Weiss 2010: C. Feldman Weiss, Performativity of Place: Movement and Water in Second Century A. D. Ephesus, in: A. Moore - G. Taylor - E. Harrus (eds.), TRAC 2009, Proceedings of the Nineteenth Annual Theoretical Roman Archaeology Conference, University of Michigan, 3-5 April 2009, University of Southampton, 17-18 April 2009 (Oxford 2010) 66-74.

Février - Blanchard-Lemée 2019: P.-A. Février - M. Blanchard-Lemée, L'édifice appelé « Maison de Bacchus » à Djemila, Études d'antiquités africaines (Paris 2019).

Golvin - Garat 2010: J.-C. Golvin - S. Garat, La restitution 3D du grand nymphée de Dougga (Tunisie), in:

R. Vergnieux - C. Delevoie (eds.), Actes du colloque Virtual Retrospect 2009, Pessac, 18-20 novembre 2009 (Bordeaux 2010) 139-144.

Hartnett 2017: J. Hartnett, The Roman Street. Urban Life and Society in Pompeii, Herculaneum, and Rome (New York 2017).

Haug - Kreuz 2016: A. Haug - P. A. Kreuz, Perspectives of Research into Sensory Perception of the City, in: A. Haug - P. A. Kreuz (eds.), Stadterfahrung als Sinneserfahrung in der römischen Kaiserzeit, Studies in classical archaeology 2 (Turnhout 2016) 295-300.

Herbert de la Portbarré-Viard 2013: G. Herbert de la Portbarré-Viard, Le munus aquarum dans le carmen 21 de Paulin de Nole: un témoignage exceptionnel sur l'évergétisme chrétien des eaux au début du Ve siècle, in: A. Dardenay - E. Rosso (eds.), Dialogues entre sphère publique et sphère privée dans l'espace de la cité romaine: vecteurs, acteurs, significations. Scripta Antiqua 56 (Bordeaux 2013) 207-231.

Hülsen et al. 1919: J. Hülsen - H. Dessau - E. Herkenrath - T. Wiegand, Milet, Ergebnisse der Ausgrabungen und Untersuchungen seit dem Jahre 1899. I 5, Das Nymphaeum (Berlin 1919).

Jacobs - Richard 2012: I. Jacobs - J. Richard, "We Surpass the Beautiful Waters of Other Cities by the Abundance of Ours." Reconciling Function and Decoration in Late Antique Fountains, Journal of Late Antiquity 5, 2012, 3-71, DoI: 10.1353/jla.2012.0000.

Jacques 1983: F. Jacques, Les curateurs des cités dans l'Occident romain de Trajan à Gallien, Etudes prosopographiques 5 (Paris 1983).

Janon 1973: M. Janon, Recherches à Lambèse: I. La ville et les camps. II. Aquae Lambaesitanae, AntAfr 7, 1973, 193-254, DoI: 10.3406/antaf.1973.1451.

Kleinwächter 2001: C. Kleinwächter, Platzanlagen nordafrikanischer Städte: Untersuchungen zum sogenannten Polyzentrismus in der Urbanistik der römischen Kaiserzeit, Beiträge zur Erschließung hellenistischer und kaiserzeitlicher Skulptur und Architektur 20 (Mainz 2001).

Lamare 2017: N. Lamare, La fontaine à cour et l'hydraulique tardive de Sbeïtla. Nouvelles observations, AntAfr 53, 2017, 95-114.

Lamare 2019: N. Lamare, Les fontaines monumentales en Afrique romaine, CEFR 557 (Rome 2019).

Lassus 1965: J. Lassus, Adaptation à l'Afrique de l'urbanisme romain, in: Le rayonnement des civilisations grecque et romaine sur les cultures périphériques, Huitième congrès international d'archéologie classique, Paris, 1963 (Paris 1965) 245-259.

Lassus 1966: J. Lassus, Une opération immobilière à Timgad, in: R. Chevallier (ed.), Mélanges d'archéologie et d'histoire offerts à André Piganiol (Paris 1966) 1221-1231.

Lassus 1972: J. Lassus, Les portiques d'Antioche, Publication of the Committee for the Excavation of Antioch and its Vicinity (Princeton 1972).

Lavan 2003: L. Lavan, Late Antique Urban Topography: from Architecture to Human Space, in: L. Lavan W. Bowden (eds.), Theory and Practice in Late Antique Archaeology, Late antique archaeology 1 (Leiden 2003) 171-195.

Lavan 2012: L. Lavan, Public Space in Late Antique Ostia: Excavation and Survey in 2008-2011, AJA 116, 2012, 649-691, DOI: 10.3764/aja.116. 4. 0649.

Lenski 2006: N. E. Lenski, Servi publici in Late Antiquity, in: J.-U. Krause - C. Witschel (eds.), Die Stadt in der Spätantike- Niedergang oder Wandel?, Akten des internationalen Kolloquiums, München, 30.-31. Mai 2003 (Stuttgart 2006) 335-357.

Lepelley 1979: C. Lepelley, Les cités de l'Afrique romaine au Bas-Empire I. La permanence d'une civilisation municipale, Collection des études augustiniennes. Série Antiquité 80 (Paris 1979).

Lepelley 1981: C. Lepelley, Les cités de l'Afrique romaine au Bas-Empire II. Notices d'histoire municipale, Collection des études augustiniennes. Série Antiquité 81 (Paris 1981).

Letzner 1999: W. Letzner, Römische Brunnen und Nymphaea in der westlichen Reichshälfte, Charybdis 2 (Münster 1999).

Leveau 1984: P. Leveau, Caesarea de Maurétanie. Une ville romaine et ses campagnes, CEFR 70 (Rome 1984).

Ling 2005: R. Ling, Street Fountains and House Fronts at Pompeii, in: S. Mols - E. M. Moormann - J. de Waele (eds.), Omni pede stare. Saggi architettonici e circumvesuviani in memoriam Jos de Waele, Studi della Soprintendenza archeologica di Pompei 9 (Naples 2005) 271-276. 
Loriot 1996: X. Loriot, Sur la datation du proconsulat d'Asie de L. Egnatus Victor Lollianus, in: A. Chastagnol S. Demougin - C. Lepelley (eds.), Splendidissima civitas. Etudes d'histoire romaine en hommage à François Jacques, Histoire ancienne et médiévale 40 (Paris 1996) 221-229.

MacDonald 1986: W. L. MacDonald, The Architecture of the Roman Empire II. An Urban Appraisal, Yale Publications in the History of Art 35 (New Haven 1986).

Magalhães de Oliveira 2012: J. C. Magalhães de Oliveira, Potestas populi: Participation populaire et action collective dans les villes de l'Afrique romaine tardive (vers 300-430 apr. J.-C.), Bibliothèque de l'Antiquité tardive 24 (Turnhout 2012).

Marano 2015: Y. Marano, “Watered... With the Life-Giving Wave." Aqueducts and Water Management in Ostrogothic Italy, in: P. Erdkamp - K. Verboven - A. J. Zuiderhoek (eds.), Ownership and Exploitation of Land and Natural Resources in the Roman world, Oxford studies on the Roman economy (Oxford 2015) 150-169 DoI: 10.1093/acprof:0so/9780198728924.003.0009.

Neudecker 1994: R. Neudecker, Die Pracht der Latrine: Zum Wandel öffentlicher Bedürfnisanstalten in der kaiserzeitlichen Stadt, Studien zur antiken Stadt 1 (Munich 1994).

Neuerburg 1965: N. Neuerburg, L’Architettura delle Fontane e dei Ninfei nell'Italia Antica, Memorie dell'Accademia di archeologia, lettere e belle arti di Napoli 5 (Naples 1965).

Poinssot - Lantier 1922: L. Poinssot - R. Lantier, Rapport sur les travaux archéologiques. I. Sbeitla, Bulletin archéologique du Comité des travaux historiques et scientifiques, 1922, pp. CXVII-CXX.

Rakob 1979: F. Rakob, Das Groma-Nymphaeum im Legionslager von Lambaesis, RM 86, 1979, 375-389.

Rakob 1993: F. Rakob (ed.), Simitthus I. Die Steinbrüche und die antike Stadt (Mainz 1993).

Rakob - Storz 1974: F. Rakob - S. Storz, Die Principia des römischen Legionslagers in Lambaesis. Vorbericht über Bauaufnahme und Grabungen, RM 81, 1974, 253-280.

Ravoisié 1846: A. Ravoisié, Exploration scientifique de l'Algérie pendant les années 1840, 1841, 1842 (Paris 1846).

Rémy et al. 2011: B. Rémy - L. Brissaud - N. Mathieu, Un service officiel des eaux (cura aquarum) à Vienne? Le témoignage d'un tuyau de plomb découvert à Saint-Romain-en-Gal (Rhône), ZPE 179, 2011, 239-243.

Richard 2012: J. Richard, Water for the City, Fountains for the People. Monumental Fountains in the Roman East, Studies in eastern Mediterranean archaeology 9 (Turnhout 2012).

Richard 2016: J. Richard, Stagnant beauties? Some Reflections on the Speed of the Water Flow in Roman Nymphaea, in: G. Wiplinger (ed.), De aquaeductu atque aqua urbium Lyciae Pamphyliae Pisidiae. The Legacy of Sextus Julius Frontinus, Tagungsband des internationalen Frontinus-Symposiums, Antalya, 31. Oktober 9. November 2014, Babesch. Supplement 27 (Leuven 2016) 275-281.

Rogers 2018: D. K. Rogers, Water Culture in Roman Society, Ancient History 1, 1 (Leiden 2018).

Ronin 2015: M. Ronin, La gestion commune de l'eau dans le droit romain. L'exemple de l'Afrique romaine et de l'Hispanie (Ier siècle avant - Ve siècle après J.-C.) (Ph.D. diss. Université de Nantes-Université Laval 2015).

Saliou 1994: C. Saliou, Les lois des bâtiments. Voisinage et habitat urbain dans l'Empire romain. Recherches sur les rapports entre le droit et la construction privée du siècle d'Auguste au siècle de Justinien, Bibliothèque archéologique et historique 116 (Beirut 1994).

Sandoz 2006: C. Sandoz, The Nymphaeum of Sabratha and the Great Severan Nymphaeum of Lepcis Magna (Libya): Supply and Hydraulic System, in: G. Wiplinger (éd.), Cura aquarum in Ephesus. Proceedings of the Twelfth International Congress on the History of Water Management and Hydraulic Engineering in the Mediterranean Region, Ephesus-Selçuk, Turkey, October 2-10, 2004, Sonderschriften des Österreichischen Archäologischen Instituts 42 = Babesch. Supplement 12 (Dudley 2006) 401-408.

Sandoz 2008: C. Sandoz, Le grand nymphée de Leptis Magna. Étude historiographique, urbanistique et architecturale (Ph.D. diss. Université Paris-Sorbonne-Université de Lausanne 2008).

Schmölder-Veit 2009: A. Schmölder-Veit, Brunnen in den Städten des westlichen Römischen Reiches, Palilia 19 (Wiesbaden 2009).

Schmölder-Veit 2010: A. Schmölder-Veit, Nymphäumsräume: Neue Treffpunkte in der spätantiken Stadt, in: N. Burkhardt - R. H. W. Stichel (eds.), Die antike Stadt im Umbruch, Kolloquium in Darmstadt, 19.-20. Mai 2006 (Wiesbaden 2010) 109-119.

Seigne 2008: J. Seigne, Fontaines et adduction d'eau à Gerasa (Jerash, Jordanie), Syria 85, 2008, 33-50, DoI: $10.4000 /$ syria. 450 .

Settis 1973: S. Settis, Esedra e ninfeo nella terminologia architettonica del mondo romano. Dall'età repubblicana alla tarda antichità, ANRW I 4,1 (Berlin 1973) 661-754.

Thébert 1999: Y. Thébert, Vie privée et architecture domestique en Afrique romaine, in: P. Veyne (ed.), Histoire de la vie privée. De l'Empire romain à l'an mil ${ }^{2}$ (Paris 1999) 301-415.

Thébert 2003: Y. Thébert, Thermes romains d'Afrique du Nord et leur contexte méditerranéen. Études d'histoire et d'archéologie, BEFAR 315 (Rome 2003), DoI: 10.4000/books.efr.2147.

Tomasello 2005: F. Tomasello, Fontane e ninfei minori di Leptis Magna, Monografie di archeologia libica 27 (Rome 2005). 
Tsafrir - Foerster 1997: Y. Tsafrir - G. Foerster, Urbanism at Scythopolis-Bet Shean in the Fourth to Seventh Centuries, DOP 51, 1997, 85-146, DoI: 10.2307/1291763.

Vannesse 2011: M. Vannesse, L'eau et l'amoenitas urbium. Étude du paysage urbain d'Antioche et d'Apamée, in: C. Abadie-Reynal - S. Provost - P. Vipard (eds.), Les réseaux d'eau courante dans l'Antiquité. Réparations, modifications, réutilisations, abandon, récupération, Actes du colloque international, Nancy, 20-21 novembre 2009, Collection archéologie et culture (Rennes 2011) 189-204.

Vendries 2014: C. Vendries, À l'écoute de la nature: L'environnement sonore des jardins d'agrément dans la civilisation romaine, in: É. Morvillez (ed.), Paradeisos. Genèse et métamorphose de la notion de paradis dans l'Antiquité, Actes du colloque international, Avignon, 20-22 mars 2009, Orient \& Méditerranée Archéologie 15 (Paris 2014) 211-230.

Ward-Perkins 1993: J. B. Ward-Perkins (ed.), The Severan Buildings of Lepcis Magna. An Architectural Survey (London 1993).

Weiß 2004: A. Weiß, Sklave der Stadt: Untersuchungen zur öffentlichen Sklaverei in den Städten des römischen Reiches, Historia. Einzelschriften 173 (Stuttgart 2004).

Wilson 2000: A. I. Wilson, Drainage and Sanitation, in: Ö. Wikander (ed.), Handbook of Ancient Water Technology, Technology and change in history 2 (Boston 2000) 151-179. 